\title{
Filtering Surgery with 5-Fluorouracil: A Second Course
}

\author{
A. OPHIR and U. TICHO \\ Jerusalem, Israel
}

\begin{abstract}
Summary
In five glaucoma patients, a previous filtering surgery that was followed by subconjunctival injections of 5-Fluorouracil (5-FU) failed, due to filtering bleb scarring. A repetition of the filtering surgery with subsequent sub-conjunctival injections of $5 \mathrm{mg}$ of 5-FU, administered once daily for 8-14 days, was undertaken. At the end of 6-19 months of follow-up, IOP levels in all five eyes were $20 \mathrm{mmHg}$ or less with medication. A repeated course of filtering surgery plus 5-FU'treatment seems to be a favourable surgical option in refractory glaucoma.
\end{abstract}

Sub-conjunctival administration of $5 \mathrm{mg}$ of 5-Fluorouracil (5-FU) following filtering surgery in aphakic/pseudophakic glaucomatous eyes and in cases of previously failed filtering surgery has been shown to be effective in the prevention of filtering bleb scarring. ${ }^{1}$ In spite of this important adjunctive treatment, surgical failures occurred in $14 \%,{ }^{2} 16 \%{ }^{3}$ and $27 \%^{1,4}$ of cases reported. In such situations, shunt implantation ${ }^{5-7}$ or cyclodestructive surgery procedures are usually tried. A repetition of the filtering surgery followed by 5-FU treatment has not been reported.

\section{Materials and Methods}

Five eyes of five patients were studied. Informed consent was obtained from all patients after the nature of the procedure had been fully explained. The age of the patients ranged from 27 to 72 years. The types of glaucoma and the different subsequent surgeries performed are listed in the Table. Prior to the surgery reported here each patient had undergone filtering surgery with sub-conjunctival injections of $5 \mathrm{mg}$ of 5-FU, which had failed due to filtering bleb scarring.
Three to seven months after this filtering surgery, trabeculectomy was performed. In four of the cases, the surgery was performed inferiorly. At the end of surgery, sub-conjunctival dexamethasone was injected and topical $1 \%$ atropine sulfate was instilled. From the first post-operative day onwards, topical $0.1 \%$ dexamethasone and $1 \%$ atropine sulfate were administered four times daily. In addition, from the first post-operative day, 5 $\mathrm{mg}$ of $5-\mathrm{FU}$ in $0.5 \mathrm{cc}$ saline was injected once daily, $180^{\circ}$ from the surgical site. Injections were continued as long as ocular inflammatory signs, ${ }^{3}$ judged by the anterior chamber reaction and/or hyperaemia at the area of the filtering bleb, were evident, altogether 8-14 days post-operatively (Table).

Patients were examined daily in the first week, twice to seven times in the second week, once in the third and fourth weeks, and again after the second, third, fourth, sixth, eighth, tenth and twelfth months.

\section{Results}

5-FU administration post-operation ranged

From: Department of Ophthalmology, Hadassah University Hospital, Jerusalem, Israel.

Correspondence to: A. Ophir, M.D., Department of Ophthalmology, Hadassah University Hospital, POB 12000, Jerusalem, Israel 91120. 
Table Data on trabeculectomy surgery with 5-FU after failure of previous filtering surgery with 5-FU treatment

\begin{tabular}{|c|c|c|c|c|c|c|c|c|c|c|c|}
\hline \multirow{2}{*}{\multicolumn{2}{|c|}{$\begin{array}{l}\text { Age/ } \\
\text { Gender }\end{array}$}} & \multirow{2}{*}{$\begin{array}{c}\text { Original } \\
\text { Glaucoma } \\
\text { type }\end{array}$} & \multirow{2}{*}{$\begin{array}{l}\text { Previous } \\
\text { surgeries }\end{array}$} & \multirow{2}{*}{$\begin{array}{l}\text { 5-FU } \\
\text { treatment } \\
(\mathrm{mg})\end{array}$} & \multicolumn{2}{|c|}{ VA } & \multicolumn{2}{|c|}{ IOP } & \multirow{2}{*}{$\begin{array}{c}\text { No. of } \\
\text { hypotensive } \\
\text { medications }\end{array}$} & \multirow{2}{*}{$\begin{array}{l}\text { Length of } \\
\text { follow-up } \\
\text { (mos) }\end{array}$} & \multirow{2}{*}{$\begin{array}{c}\text { Corneal } \\
\text { epithelial } \\
\text { defects }\end{array}$} \\
\hline & & & & & Pre-op. & post-op. & pre-op. & post-op & & & \\
\hline 1 & $61 \mathrm{~F}$ & Ps.P & $\begin{array}{l}\text { Cat + IOL } \\
\text { TRB +5-FU }\end{array}$ & 45 & $20 / 40$ & $20 / 40$ & 28 & 16 & 2 & 11 & absent \\
\hline 2 & $55 \mathrm{~F}$ & Ps.P & $\begin{array}{l}\mathrm{Cat}+\mathrm{IOL} \\
\mathrm{TRB}+5-\mathrm{FU}\end{array}$ & 40 & $20 /-60$ & $20 / 40$ & 30 & 17 & 1 & 13 & absent \\
\hline 3 & $72 \mathrm{M}$ & Ps.P & $\begin{array}{l}\mathrm{Cat}+\mathrm{IOL} \\
\mathrm{TRB}+5-\mathrm{FU}\end{array}$ & 70 & $\begin{array}{l}2 \mathrm{~m} \\
\mathrm{FC}\end{array}$ & $\begin{array}{l}3 \mathrm{~m} \\
\mathrm{FC}\end{array}$ & 48 & 19 & 3 & 16 & present \\
\hline 4 & $27 \mathrm{~F}$ & JUV & $\begin{array}{l}\text { TRO } \\
\text { TRB } \\
\text { Molteno } \\
\text { shunt } \\
\text { PLS+5-FU }\end{array}$ & 55 & $20 / 200$ & $20 / 200$ & 34 & 20 & 4 & 19 & present \\
\hline 5 & $30 \mathrm{M}$ & $\begin{array}{l}\text { Steroid- } \\
\text { induced }\end{array}$ & $\begin{array}{l}\text { TRB } \\
\text { TRB +5-FU }\end{array}$ & 40 & $\begin{array}{l}3 \mathrm{~m} \\
\mathrm{FC}\end{array}$ & $\begin{array}{l}3 \mathrm{~m} \\
\mathrm{FC}\end{array}$ & 37 & 17 & 1 & 6 & absent \\
\hline & $\begin{array}{l}\mathrm{JV} \\
\mathrm{t}+\mathrm{IOL}\end{array}$ & $\begin{array}{l}=\text { Pseu } \\
=\text { Juver } \\
=\text { Extra }\end{array}$ & $\begin{array}{l}\text { lophakia } \\
\text { ile } \\
\text { capsular Catar }\end{array}$ & act extractio & + IOL im & tation & & $\begin{array}{l}=\text { Tra } \\
=\text { Tra } \\
=\text { Pos }\end{array}$ & $\begin{array}{l}\text { culotomy } \\
\text { culectomy } \\
\text { rior lip sclerec }\end{array}$ & omy & \\
\hline
\end{tabular}

from 40 to $70 \mathrm{mg}$. IOP fell from a pre-operative value of $35 \pm 9.0 \mathrm{mmHg}$ (range, 28 to 48 $\mathrm{mmHg}$ ) to a post-operative value of $17.25 \pm 1.26 \mathrm{mmHg}$ (range, 16 to $20 \mathrm{mmHg}$ ), $13 \pm 4.95$ months. (range, 6 to 19 ) after surgery (Table). Whereas pre-operatively all five eyes were treated by four hypotensive medications, a mean of $2.2 \pm 1.3$ medications were given post-operatively.

Side-effects included punctate corneal erosions in two (40\%) eyes (Table) and conjunctival epithelial defects at the injection site in three $(60 \%)$ eyes.

\section{Discussion}

A repetition of filtering surgery followed by 5-FU treatment was performed in three pseudophakic glaucomous eyes, as a third filtering operation in one other eye, and a fourth filtering operation in a fifth eye. In all five eyes, IOP levels after six to 19 months follow-up were $20 \mathrm{mmHg}$ or lower, all with hypotensive medication. Several theoretical reasons can be postulated for the success rate of the second rather than the first course of filtering surgery and 5-FU treatment. Among the possible explanations are undetectable bleeding or significant inflammation in the surgical area that promote scarring ${ }^{8,9}$ and lack of compliance of patients following the first operation.

The accepted options following failure of filtering surgery plus 5-FU treatment are aqueous shunt implantation or a cyclodestructive procedure, but both are probably more risky than the approach presented in this report: Minckler and colleagues ${ }^{10}$ reported that $63 \%(26 / 46)$ of aphakic/pseudophakic glaucoma patients had final post-operative IOP of $21 \mathrm{mmHg}$ or lower (at least six months follow-up), following a single-plate Molteno implantation. However, complications in a total of 90 patients included post-operative choroidal haemorrhage $(8 \%)$, cataract $(7 \%)$, tube block $(6 \%)$, phthisis bulbi $(2 \%)$, hypotony $(2 \%)$, traction retinal detachment $(2 \%)$, pupillary membrane $(1 \%)$ and recurrent vitreous haemorrhage $(1 \%)$. Schocket and associates implanted an anterior chamber tube shunt attached to an encircling band and reported on a successful outcome in four out of five eyes, with average IOP of $19.8 \mathrm{mmHg}$ in non-neovascular refractory glaucoma. Due to corneal touch by the shunt, a retrocorneal membrane developed in the fifth eye, with resultant increased IOP and reduced visual acuity. ${ }^{6}$

Krupin and associates ${ }^{7}$ implanted a long Krupin-Denver valve attached to a $180^{\circ}$ scleral explant in eyes in which prior filtration surgery had failed. After follow-up of 21 months (mean) IOP was less than $21 \mathrm{mmHg}$ in $82 \%(27 / 33)$ of eyes; $56 \%$ of these eyes required additional medication. However, post-operative choroidal detachment with associated reduction in IOP and shallowing of the anterior chamber frequently occurred $(11 / 33$ of eyes $=33 \%)$. In eyes with a flat anterior chamber, the tube contacted the cornea or lens.

The effectiveness of cyclocryotherapy in lowering IOP to avoid further surgery is 
reported as between $30-60 \%$ (11/12) depending on the type of refractory glaucoma being treated. The complications of cyclotherapy are well documented and include choroidal detachment with a flat anterior chamber, phthisis bulbi, loss of light perception, sympathetic ophthalmia, scleral thinning with resulting staphyloma, hyphaema, iritis, corneal oedema, iris atrophy, retinal detachment, cataract and vitreous haemorrhage. Brindley and Shields reported that after cyclocryotherapy, $60 \%$ of the eyes lost some vision with a phthisis bulbi rate of $12 \%$ (13).

The significant risks of phthisis and visual loss with cyclocryotherapy have led to the development of other techniques of cilioablation such as Neodymium:YAG cyclophotocoagulation (Nd:YAG-CPC), argon laser transpupillary or transiridectomy cyclophotocoagulation and therapeutic ultrasonogrpahy. It is the higher rate rather than the type of complications reported that distinguishes cyclocryotherapy from Nd:YAG-CPC. ${ }^{14}$

Trope and $\mathrm{Ma}^{15}$ reported that $30 \%$ of 28 eyes with good IOP control lost some vision after Nd:YAG-CPC, and the phthisis bulbi rate was $10.7 \%$. Although this procedure appears to be effective, it is asociated with significant complications.

Serious complications have also been described after the use of transscleral ruby laser cyclocoagulation. ${ }^{16}$ Currently, there are no studies comparing Nd:YAG-CPC or other forms of therapy, including cyclotherapy, to trabeculectomy with injections of antimetabolites.

First-time course of filtering surgery and 5-FU was only rarely accompanied by permanent complications, ${ }^{1,4}$ unless this treatment was administered in eyes with pre-operative bullous keratopathy ${ }^{17}$ or corneal oedema. ${ }^{1}$ The second course of surgery with 5-FU was undertaken as early as three months after the preceding course (Case No. 5) and as late as seven months after the preceding course (Case No. 4). Side-effects following the second course of filtering surgery and 5-FU treatment reported here, were similar to those reported after a first course. ${ }^{1-4}$ Neither serious side-effects nor permanent complications were observed following the second use of s.c. 5-FU reported here.
The small sample presented here precludes significance, however the results may have clinical importance: in the five poor-prognosis glaucomatous eyes, IOP levels were 20 $\mathrm{mmHg}$ or lower, although all with hypotensive medication. In addition, from this preliminary study it does seem that a second course of filtering surgery plus 5-FU treatment is safer than the alternatives mentioned above. A larger number of patients is needed to verify the results of this study.

\section{References}

${ }^{1}$ The Fluorouracil Filtering Surgery Study Group: Fluorouracil filtering surgery study one year follow-up. Am J Ophthalmol 1989, 108: 625-35.

${ }^{2}$ Weinreb RN: Adjusting the dose of 5-Fluorouracil after filtration surgery to minimise side effects. Ophthalmol 1987, 94: 564-70.

${ }^{3}$ Ophir A and Ticho U: Adjusting of 5-Fluorouracil dosage after filtering surgery according to anterior chamber inflammation. Abstract. Presented at the International Symposium on Ocular Inflammation, Alicante, Spain, 1990.

${ }^{4}$ Heuer DK, Parrish RK II, Gressel MG, Hodapp E, Desjardins DC, Skuta GL, Palmberg PF, Nevarez JA, Rockwood EJ: 5-Fluorouracil and glaucoma filtering surgery. III Intermediate follow-up of a pilot study. Ophthalmol 1986, 93: 1537-46.

${ }^{5}$ Molteno ACB, Van Rooyen MMB, Bartholomew RS: Implants for draining neo-vascular glaucoma. Am J Ophthalmol 1977, 61: 120-5.

${ }^{6}$ Schocket SS, Nirankari VS, Lakhanpal V, Richards RD, Lerner BC: Anterior chamber tube shunt to an encircling band in the treatment of neovascular glaucoma and other refractory glaucomas: a longterm study. Ophthalmol 1985, 92: 553-62.

${ }^{7}$ Krupin T, Podos SM, Becker B, Newkirk JB: Valve implants in filtering surgery. Am J Ophthalmol 1976, 81: 232-5.

${ }^{8}$ Friedenwald JS: Some problems in the diagnosis and treatment of glaucoma. Am J Ophthalmol 1950, 33: $1523-38$.

${ }^{9}$ Maumenee AE: External filtering operations for glaucoma: The mechanism of function and failure. Trans Am Opthalmol Soc, 1960, 58: 319-28.

${ }^{10}$ Minckler DS, Heuer DK, Hasty B, Baerveldt J, Cutting RC, Barlow WE: Clinical experience with the single-plate Molteno implant in complicated glaucomas. Opthalmol 1988, 95: 1181-8.

${ }^{11}$ Shields MB: Cyclodestructive surgery for glaucoma: past, present and future. Trans Am Ophthalmol Soc 1985, 83: 285-303.

${ }^{12}$ Bellows AR: Cyclotherapy for glaucoma. Int Ophthalmol Clin 1981, 21: 99-111.

${ }^{13}$ Brindley $\mathrm{G}$ and Shields MB: Value and Limitations of Cyclocryotherapy. Graefes Arch Clin Exp Ophthalmol 1986, 224: 545-8.

${ }^{14}$ Maus M and Katz LJ: Choroidal detachment, flat anterior chamber and hypotony at complications of Neodymium:YAG laser cyclophotocoagulation. Ophthalmol 1990, 97: 69-72. 
${ }^{15}$ Trope GE and Ma S: Mid-term effects of Neodymium:YAG transscleral cyclocoagulation in glaucoma. Ophthalmol 1990, 97: 73-5.

${ }^{16}$ Beckman H and Waeltermann J: Transscleral ruby laser cyclocoagulation. Am J Ophthalmol 1984,
98: 788-95.

${ }^{17}$ Knapp A, Heuer DK, Stern GA, Driebe WT: Serious corneal complications of glaucoma filtering surgery with post-operative 5-Fluorouracil. Am J Ophthalmol 1987, 103: 183-7. 